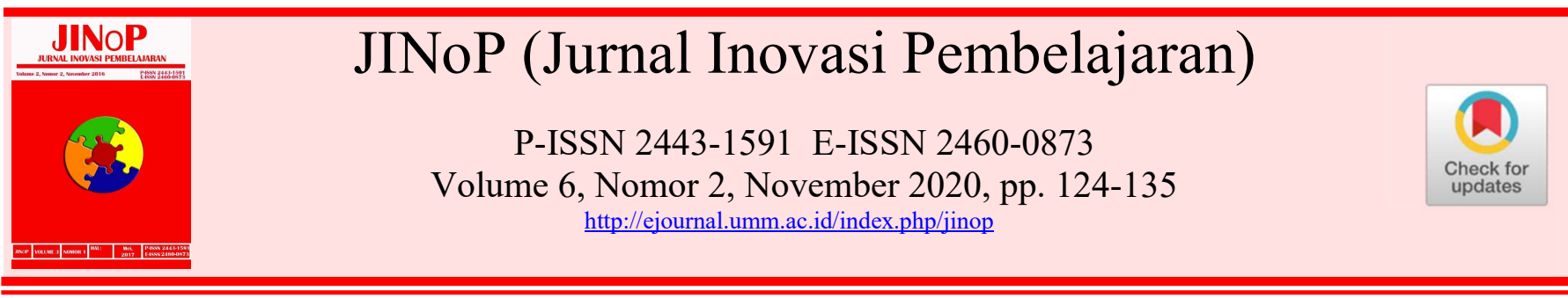

\title{
Pengembangan puzzle square sebagai media pembelajaran interaktif menggunakan macromedia flash 8
}

\author{
Sabarudin Saputra ${ }^{1)}$, Tanti Diyah Rahmawati ${ }^{2)^{*}}$, Nurfitriah Safrudin ${ }^{3)}$ \\ ${ }^{1}$ Pendidikan Matematika, Fakultas Pendidikan Matematika dan IPA, IKIP Muhammadiyah \\ Maumere, J1. Jenderal Sudirman, Sikka, Indonesia \\ ${ }^{2}$ Pendidikan Matematika, Fakultas Pendidikan Matematika dan IPA, IKIP Muhammadiyah \\ Maumere, Jl. Jenderal Sudirman, Sikka, Indonesia \\ ${ }^{3}$ Pendidikan Matematika, Fakultas Pendidikan Matematika dan IPA, IKIP Muhammadiyah \\ Maumere, Jl. Jenderal Sudirman, Sikka, Indonesia \\ sabarudinsaputra15@gmail.com; t4ant1dr@gmail.com*; nurfitriahsafrudin8@gmail.com \\ *Penulis Koresponden
}

\begin{tabular}{|c|c|}
\hline & ABSTRAK \\
\hline & $\begin{array}{l}\text { Matematika merupakan ilmu yang bersifat abstrak karena menuntut siswa mengonstruksi } \\
\text { pengetahuan melalui proses menerjemahkan berbagai lambang. Hal ini menyebabkan perlunya } \\
\text { media yang bersifat interaktif, menyenangkan, dan mudah diakses. Tujuan penelitian ini adalah } \\
\text { mengembangkan media pembelajaran interaktif puzzle square menggunakan macromedia flash } 8 \\
\text { dan menganalisis kelayakan media tersebut dalam pembelajaran Teorema Pythagoras di kelas } \\
\text { VIII SMP Negeri } 1 \text { Maumere. Penelitian dan pengembangan ini menerapkan model ADDIE yang } \\
\text { terdiri dari analisis masalah awal, desain model media, proses pengembangan dan revisi, } \\
\text { penerapan atau uji coba, dan evaluasi hasil penerapan. Hasil penelitian ini yaitu dihasilkannya } \\
\text { media berupa aplikasi pembelajaran puzzle square yang dapat diakses menggunakan komputer } \\
\text { atau laptop. Media pembelajaran interaktif puzzle square dinyatakan baik berdasarkan rata-rata } \\
\text { skor penilaian ahli materi dan ahli media sebesar } 4,18 \text { dan media pembelajaran interaktif puzzle } \\
\text { square dinyatakan sangat baik berdasarkan rata-rata penilaian peserta didik mencapai } 4,22 \text {. } \\
\text { Dengan demikian media pembelajaran interaktif puzzle square layak digunakan dalam } \\
\text { pembelajaran matematika pada materi Teorema Pythagoras untuk siswa kelas } 8 \text { SMP Negeri } 1 \\
\text { Maumere. } \\
\text { Kata kunci: Macromedia Flash 8; Media Pembelajaran Interaktif; Puzzle Square; Pythagoras. }\end{array}$ \\
\hline & ABSTRACT \\
\hline & 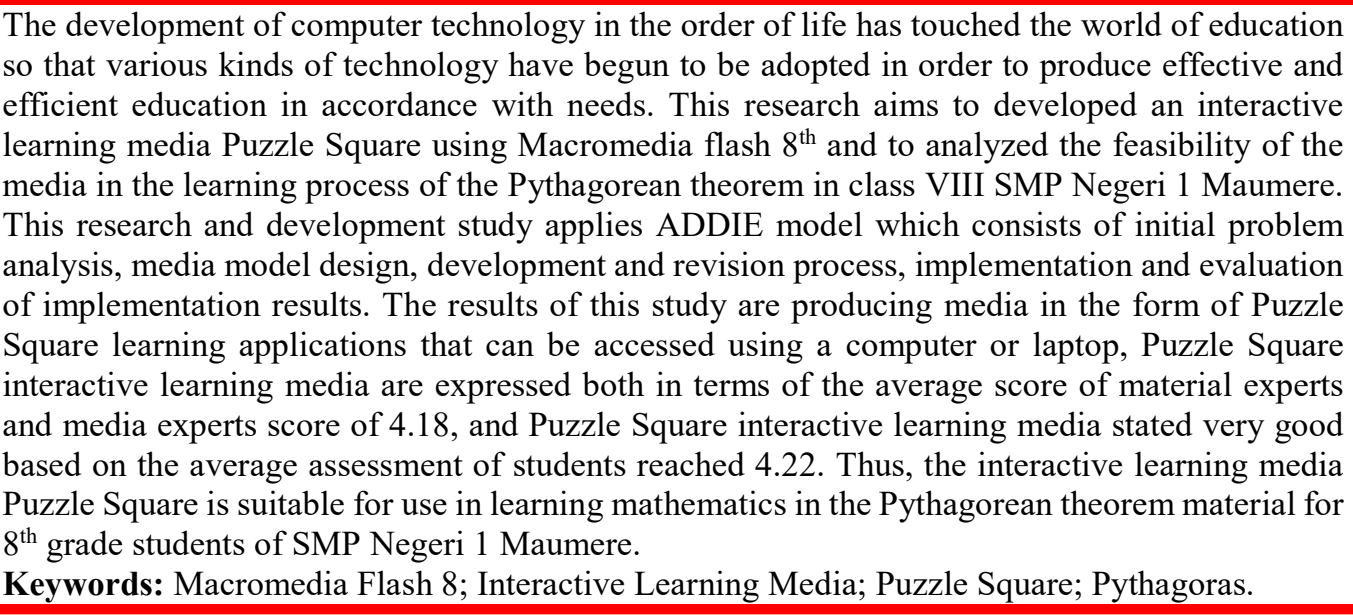 \\
\hline & $\begin{array}{l}\text { diunggah: 2020-05-06, direvisi: 2020-06-07, diterima: 2020-11-20, dipublikasi: 2020-11-20 } \\
\text { Copyright (c) } 2020 \text { Saputra et al } \\
\text { This is an open access article under the CC-BY license }\end{array}$ \\
\hline
\end{tabular}


Cara sitasi: Saputra, S., Rahmawati, T., \& Safrudin, N. (2020). Pengembangan puzzle square sebagai media pembelajaran interaktif menggunakan macromedia flash 8. JINoP (Jurnal Inovasi Pembelajaran), 6(2). doi:https://doi.org/10.22219/jinop.v6i2.12096

\section{PENDAHULUAN}

Pesatnya perkembangan teknologi informasi saat ini merambah hingga ke dunia pendidikan. Globalisasi mengarahkan perkembangan teknologi agar bermanfaat dalam proses pembelajaran demi meningkatkan mutu pendidikan. Teknologi informasi adalah hasil penerapan ilmu pengetahuan yang terorganisir secara sistematis untuk menyelesaikan permasalahan secara praktis menggunakan sistem informasi yang menggabungkan teknologi komputer dengan telekomunikasi (Budiman, 2017; Nurdyansyah et al., 2015).

Teknologi informasi telah diperhatikan perkembangannya oleh berbagai lembaga dengan tingkatannya masing-masing. Perkembangan tersebut kemudian diupayakan agar dapat memberikan manfaat terhadap aspek pendidikan dengan membangun infrastruktur hardware, pengadaan sofware, jaringan internet, dan lain sebagainya yang dapat dilakukan oleh berbagai praktisi pendidikan baik itu peneliti, ahli, tenaga pendidik, institusi dan lembaga-lembaga yang berkaitan dengan pendidikan.

Perkembangan teknologi sebagai dampak dari globalisasi telah merubah wajah pendidikan pada berbagai tingkatannya. Pada tingkat satuan pendidikan sekolah hingga perguruan tinggi, teknologi mengambil peran dalam merubah pembelajaran konvensional menjadi pembelajaran interaktif. Perkembangan tersebut diharapkan dapat membuat pendidikan di kemudian hari bersifat fleksibel, terbuka dan dapat dirasakan oleh siapapun dan dimanapun (Asmawi et al., 2019).

Kontribusi nyata perkembangan teknologi dalam pendidikan adalah pemanfaatan media untuk proses belajar mengajar serta dirancang sesuai dengan kebutuhan kompetensi yang diupayakan keterlibatan alat komunikasi berupa media pembelajaran. Media pada umumnya diartikan sebagaialat penyaluran pesan dalam proses pembelajaran berupa rangsangan terhadap indera sehingga mempengaruhi keinginan belajar peserta didik (Hidayati, 2018; Muhayat et al., 2017; Putri et al., 2019)

Matematika merupakan ilmu yang bersifat abstrak dan dipelajari pada berbagai jenjang pendidikan (Crismono, 2017; Masykur et al., 2017). Sifat abstrak matematika tersebut menuntut manusia mengkonstruksi pengetahuan melalui proses menerjemahkan berbagai macam lambang yang dirasa sulit untuk dimengerti (Masykur et al., 2017; Mustamid \& Raharjo, 2015; Setiawan \& DS, 2013). Hal itu menyebebkan perlunya media untuk memvisualisasikan matematika menjadi nyata dan mudah dipahami dengan proses yang menyenangkan.

Pemanfaatan media dalam proses pembelajaran dimaknai bukan hanya sebagai penggunaan alat tetapi juga tentang proses memberikan rangsangan komunikasi sehingga terjadi proses belajar (Kurniawan \& Saragih, 2016; Susilana \& Riyana, 2009). Media pembelajaran menjadi objek pendukung kesuksesan proses pembelajaran yang ditunjukkan dengan tersampaikannya rangsangan dari pendidik ke peserta didik maupun sebaliknya (Ahern, 2016; Khairani \& Febrinal, 2016). Proses pemberian rangsangan menggunakan media membutuhkan teknik pembelajaran agar komunikasi antara pendidik dan peserta didik menjadi efektif (Wati, 2016). Berdasarkan hal itu maka media yang diperlukan adalah media yang bersifat interaktif dan mudah diakses untuk proses belajar (Masykur et al., 2017). 
Media pembelajaran interaktif merupakan media yang berbentuk software dan hardware serta dapat diakses secara mandiri tanpa melibatkan pendidik secara langsung sehingga memupuk kemandirian dalam proses belajar peserta didik (Widjayanti et al., 2018).

Media pembelajaran interaktif dapat dibuat menggunakan berbagai macam software dan hardware untuk menggabungkan video animasi dan audio sekaligus. Salah satu hardware yang dapat digunakan adalah komputer dengan software pendukung berupa aplikasi Macromedia flash 8 (Akhmadan, 2017; Masykur et al., 2017). Macromedia flash 8 adalah software pembuat animasi berupa huruf maupun gambar yang ditunjang dengan berbagai elemen untuk menghasilkan media pembelajaran berupa animasi web, game, presentasi maupun $C D$ pembelajaran (Fahmi, 2014).

Media pembelajaran interaktif Puzzle Square merupakan media penunjang dalam proses belajar di kelas maupun dapat digunakan secara individual. Pemilihan permainan puzzle sebagai media dikarenakan puzzle merupakan permainan yang mengharuskan pemainnya membuat gambar utuh dari kepingan gambar yang disediakan secara konstruktif, bersifat menghibur dan dapat meningkatkan kecerdasan visual-spatial, menambah pengetahuan, melatih koordinasi alat indera dengan otak, serta melatih kemampuan nalar (Anjani \& Nurjanah, 2018; Fatimah et al., 2017; Hidayati, 2018). Pengembangan Puzzle Square didasarkan pada rendahnya pemanfaatan teknologi sebagai media dalam proses pembelajaran khususnya pada bab Teorema Pythagoras di Kelas VIII SMP. Oleh sebab itu maka inovasi media pembelajaran harus dilakukan menyesuaikan dengan perkembangan teknologi.

Perkembangan teknologi yang dimaksud adalah telah tersedianya fasilitas komputer di sekolah sebagai upaya memajukan pendidikan sebagaimana yang dicita-citakan dalam sistem pendidikan nasional. SMP Negeri 1 Maumere merupakan salah satu sekolah yang sangat memperhatikan ketersediaan fasilitas untuk menunjang proses pembelajaran. Salah satu fasilitas yang penting untuk disediakan adalah laboratorium komputer. Keberadaan komputer dalam proses pembelajaran merupakan hal yang penting sehingga pendidik dan peserta didik dapat memanfaatkannya sebagai media pembelajaran yang efektif.

Keberadaan laboratorium di sekolah pada kenyataannya lebih sering digunakan dalam proses ujian, baik itu ujian sekolah maupun ujian nasional. Selain itu komputer-komputer yang tersedia hanya digunakan dalam proses belajar mengenal komputer, bukan bagaimana menggunakan komputer sebagai media dalam proses pembelajaran. Kenyataannya bahwa komputer sangat berguna dalam mengembangkan pembelajaran interaktif yang tidak berpusat pada pendidik semata. Pembelajaran dengan pendekatan saintifik menuntut peserta didik menemukan dan menganalisis informasi tentang kebutuhan materi secara mandiri dengan memperhatikan arahan pendidik. Terlepas dari kemampuan penguasaan teknologi komputer oleh para pendidik, komputer-komputer yang tersedia perlu dimanfaatkan oleh pendidik maupun peserta didik dalam mengakses materi pembelajaran secara mandiri.

Ketersediaan komputer di sekolah juga perlu didukung dengan ketersediaan software atau program lainnya yang dapat diakses oleh pendidik maupun peserta didik. Secara garis besar, seluruh proses pembelajaran dapat diintegrasikan dengan komputer sebagai alat untuk menyampaikan materi. Peserta didik yang membutuhkan informasi tambahan tentang materi dapat langsung mengaksesnya 
dari program komputer yang telah disediakan. Berdasarkan hal itu maka penelitian ini bertujuan untuk mengembangkan media pembelajaran interaktif Puzzle Square menggunakan Macromedia flash 8 sebagai sebuah program aplikasi komputer dan menganalisis kelayakannya sehingga dapat dimanfaatkan oleh pendidik atau peserta didik pada materi teorema Pythagoras.

Penelitian yang menjadi acuan dikembangkannya Puzzle Square ini adalah pengembangan media oleh Mas'ud Rifai \& Erlina Prihatnani pada tahun 2020. Pengembangan tersebut menghasilkan media pembelajaran bernama PuPPy yang berbentuk papan puzzle. Papan puzzle tersebut digunakan khusus untuk membantu siswa dalam membuktikan teorema Pythagoras. Hasil analisis data penilaian media PuPPy yang dibuat menggunakan model ADDIE ini valid dan efektif untuk membuktikan teorema Pythagoras.

Media PuPPy yang dihasilkan kemudian dikembangkan kembali mengingat media ini tidak memanfaatkan perkembangan teknologi. Penelitian ini menggunakan model ADDIE dengan tujuan untuk membantu siswa memahami sub materi pembuktian teorema Pythagoras secara menyenangkan dan mandiri menggunakan konsep puzzle dan dikemas dalam bentuk aplikasi pembelajaran sehingga dapat diakses dengan mudah menggunakan komputer. Model pengembangan ADDIE memuat prosedur yang mencakup beberapa tahapan yaitu analisis kebutuhan media, perancangan media, pengembangan media, penerapan media, dan penilaian media (Lee \& Owens, 2012; Rifai \& Prihatnani, 2020).

Puzzle Square hasil pengembangan merupakan media yang terdiri dari pembahasan materi pembelajaran secara sistematis, permainan, dan evaluasi untuk mengukur kemampuan kognitif serta melatih keterampilan dan kerja sama peserta didik. Hasil pengembangan berbentuk aplikasi yang dapat dijalankan melalui PC atau laptop, dan sejenisinya dengan spesifikasi rendah sehingga dapat digunakan pada berbagai sistem operasi Windows yang sedang marak digunakan.

\section{METODE}

Jenis penelitian ini adalah Research and Development $(R \& D)$ yang bersifat prosedural untuk mengembangkan produk dengan menjelaskan langkah-langkah berupa tahap analisis potensi dan masalah, mengumpulkan data untuk perencanaan, membuat desain, pengembangan berdasarkan desain, penilaian atau validasi oleh ahli, revisi berdasarkan penilaian ahli, uji coba terbatas dan penilaian produk oleh peserta didik, revisi hasil, uji coba kelompok besar dan penilaian oleh peserta didik, serta finalisasi produk yang dikemas dalam model pengembangan ADDIE (Pradipta \& Andajani, 2017; Sugiyono, 2012).

Tahap penilaian dan uji coba media dalam penelitian ini dilakukan dua kali dengan melibatkan satu orang ahli media dan satu orang ahli materi. Setelah produk dinilai oleh ahli dan direvisi, dilakukan uji coba media oleh peserta didik yang merupakan subjek penelitian. Subjek dalam penelitian ini adalah peserta didik kelas VIII E SMP Negeri 1 Maumere. Lama waktu penelitian adalah sejak tanggal 27 Januari 2020 sampai dengan 27 Februari 2020.

Penilaian peserta didik dilakukan dua kali yaitu pada uji coba terbatas yang melibatkan 10 orang peserta dan uji coba kelompok besar yang melibatkan 31 orang peserta didik. Berdasarkan penilaian uji coba terbatas produk perlu direvisi. Hasil penilaian dan revisi produk dalam uji coba terbatas, digunakan dalam uji coba kelompok besar. Berdasarkan penilaian uji coba kelompok besar, produk perlu 
difinalisasi untuk menghasilkan media pembelajaran Puzzle Square yang layak digunakan.

Instrumen penelitian ini adalah angket penilaian kelayakan media untuk ahli materi, ahli media, dan peserta didik berupa indikator-indikator yang disusun berdasarkan kebutuhan penilaian dengan memperhatikan masukan dari validator instrumen. Angket merupakan teknik pengumpulan data dengan cara memberikan beberapa pertanyaan tertulis untuk memperoleh informasi dari responden atau subjek penelitian mengenai suatu hal. Angket yang digunakan bersifat tertutup dimana jawaban dari pertanyaan telah ditentukan sehingga responden tinggal membubuhkan tanda pada kolom jawaban yang telah ditentukan berupa angkaangka yang memiliki tingkatan-tingkatan (rating scale). Data yang dihasilkan merupakan data kualitatif berupa komentar dan saran dari ahli sebagai bahan untuk melakukan perbaikan dan data kuantitatif dari ahli dan peserta didik yang mengacu pada tabel 1. Pedoman Skor Pengisian Angket (Sugiyono, 2012) berikut:

Tabel 1. Pedoman Skor Pengisian Angket

\begin{tabular}{cc}
\hline Skor & Penilaian \\
\hline 5 & Sangat baik \\
4 & Baik \\
3 & Cukup baik \\
2 & Kurang baik \\
1 & Sangat kurang \\
\hline
\end{tabular}

Data kuantitatif pada angket penilaian kelayakan produk kemudian dianalisis menggunakan perhitungan rata-rata $(X)$ terhadap total skor yang dihasilkan. Menurut Sukardjo dalam (Setyawati, 2017) skor rata-rata $(X)$ menjadi dasar penilaian tingkat kelayakan media mengacu pada tabel 2. Pedoman Konversi Penilaian Tingkat Kelayakan Produk berikut:

Tabel 2. Pedoman Konversi Penilaian Tingkat Kelayakan Media

\begin{tabular}{cc}
\hline Kriteria & Skor \\
\hline Sangat layak & $X>4,2$ \\
Layak & $3,4<X<4,2$ \\
Cukup layak & $2,6<X<3,4$ \\
Kurang Layak & $1,8<X<2,6$ \\
Tidak Layak & $X \leq 1,8$ \\
\hline
\end{tabular}

$X$ pada tabel merupakan rata-rata skor pada angket penilaian oleh ahli dan peserta didik yang menjadi dasar pengambilan keputusan mengenai kelayakan produk sesuai kriteria yang tertera.

\section{HASIL DAN PEMBAHASAN Analysis (Analisis)}

Tahap awal penelitian yaitu menganalisis keadaan lapangan dan kebutuhan kurikulum materi teorema Pythagoras yang digunakan di kelas VIII E SMP Negeri 1 Maumere. Keadaan lapangan menunjukkan bahwa pembelajaran teorema Pythagoras tidak memanfaatkan teknologi sebagai media pembelajaran. Pembelajaran berlangsung dengan memanfaatkan buku dan literatur penunjang lain tanpa pemanfaatan media sebagai upaya interaksi dalam pembelajaran antara pendidik dan peserta didik secara berkelanjutan dan sistematis. Peserta didik mendapatkan pemahaman materi dari pendidik sebagai pihak perantara sehingga 
peserta didik tidak dapat berhubungan langsung dengan materi pembalajaran secara mandiri.

Kompetensi dasar (KD) pembelajaran pada materi teorema Pythagoras menjadi acuan pengembangan materi ajar yang akan ditampilkan dalam media pembelajaran. Analisis dilakukan dengan menjabarkan kompetensi dasar menjadi indikator pencapaian kompetensi pembelajaran. Penjabaran KD materi teorema Pythagoras dalam pembelajaran secara sederhana ditunjukkan pada tabel 3 . Kompetensi dasar dan Indikator Pencapaiam Kompetensi berikut:

Tabel 3. Kompetensi dasar dan Indikator Pencapaiam Kompetensi

\begin{tabular}{llll}
\hline \multicolumn{1}{c}{ Kompetensi Dasar } & \multicolumn{1}{c}{ Indikator Pencapaian } \\
\hline 3.6 & $\begin{array}{l}\text { Menjelaskan dan membuktikan } \\
\text { kebenaran teorema Pythagoras dan } \\
\text { triple Pythagoras. }\end{array}$ & 3.6 .1 & $\begin{array}{l}\text { Memeriksa kebenaran teorema } \\
\text { Pythagoras. }\end{array}$ \\
& 3.6 .2 & $\begin{array}{l}\text { Menentukan panjang sisi segitiga siku- } \\
\text { siku jika panjang dua sisi diketahui. }\end{array}$ \\
\hline
\end{tabular}

Media pembelajaran Puzzle Square didesain untuk mencapai indikator yang telah dirumuskan. Pengembangan media ini dibatasi pada kompetensi dasar 3.6 yang berhubungan dengan pemahaman. Pada dasarnya, media pembelajaran yang akan dikembangkan tentu bukan sarana atau media utama yang digunakan. Media ini menjadi salah satu pilihan oleh pengguna untuk dapat menarik perhatian dengan desain video animasi dan halaman interaktif.

Teorema Pythagoras merupakan materi dasar yang penting untuk diketahui. Konsep dan rumusan teorema Pythagoras dapat dibuktikan dan diterapkan dalam menyelesaikan permasalahan sederhana maupun kompleks. Konsep Pythagoras telah banyak dibuktikan dengan berbagai cara. Agar tercipta sebuah inovasi baru dengan memanfaatkan perkembangan teknologi, teorema Pythagoras dibuktikan menggunakan konsep puzzle yang diadaptasi ke dalam program Macromedia Flash 8. Namun tidak sebatas pembuktian, media juga memuat pemaparan materi penguat agar sesuai dengan kompetensi yang akan dicapai. Setelah mengetahui muatan materi maka dilanjutkan dengan perencanaan.

\section{Design (Perancangan)}

Hasil analisis kemudian menjadi dasar melakukan perencanaan media berupa flowchart dan storyboard. Flowchart menggambarkan alur pengoperasian media pembelajaran pada perangkat komputer secara garis besar, sedangkan storyboard merupakan model dasar yang dijadikan garis besar dalam pembuatan media pembelajaran. Storyboard menampilkan dengan jelas letak unsur-unsur yang ditampilkan pada media pembelajaran (Yektyastuti \& Ikhsan, 2016). Flowchart dan storyboard dirancang per halaman atau per sub bahasan dalam materi pembelajaran.

\section{Development (Pengembangan) \& Revision (Revisi)}

Pengembangan media dilakukan dengan menggunakan model ADDIE yang disampaikan oleh (Lee \& Owens, 2012) melalui 5 tahap yaitu, Menanalisis; Merancang; Mengembangkan; Menguji cobakan; dan Menilai (Rifai \& Prihatnani, 2020). Pengembangan media pembelajaran Puzzle Square diperuntukan bagi peserta didik kelas VIII SMP Negeri 1 Maumere pada materi teorema Pythagoras. Pembuatan media memanfaatkan Macromedia Flash 8 dengan hasil pengembangan berupa aplikasi pembelajaran berekstensi exe. Sebagaimana yang disampaikan 
oleh (Masykur et al., 2017; Widjayanti et al., 2018) tentang defenisi media pembelajaran interaktif maka aplikasi pembelajaran Puzzle Square memuat tombol navigasi sehingga dapat diklik langsung oleh peserta didik menggunakan komputer agar peserta didik tidak terpaku dengan komunikasi yang tercipta antara pendidik dan peserta didik saja. Aplikasi tersebut dapat dijalankan pada komputer dengan sistem operasi windows 7, 8, 8.1, dan 10 .

Produk hasil pengembangan media pembelajaran materi teorema Pythagoras yang dapat dioperasikan pada perangkat komputer sebelum dinilai oleh ahli secara umum ditampilkan oleh gambar 1. berikut:

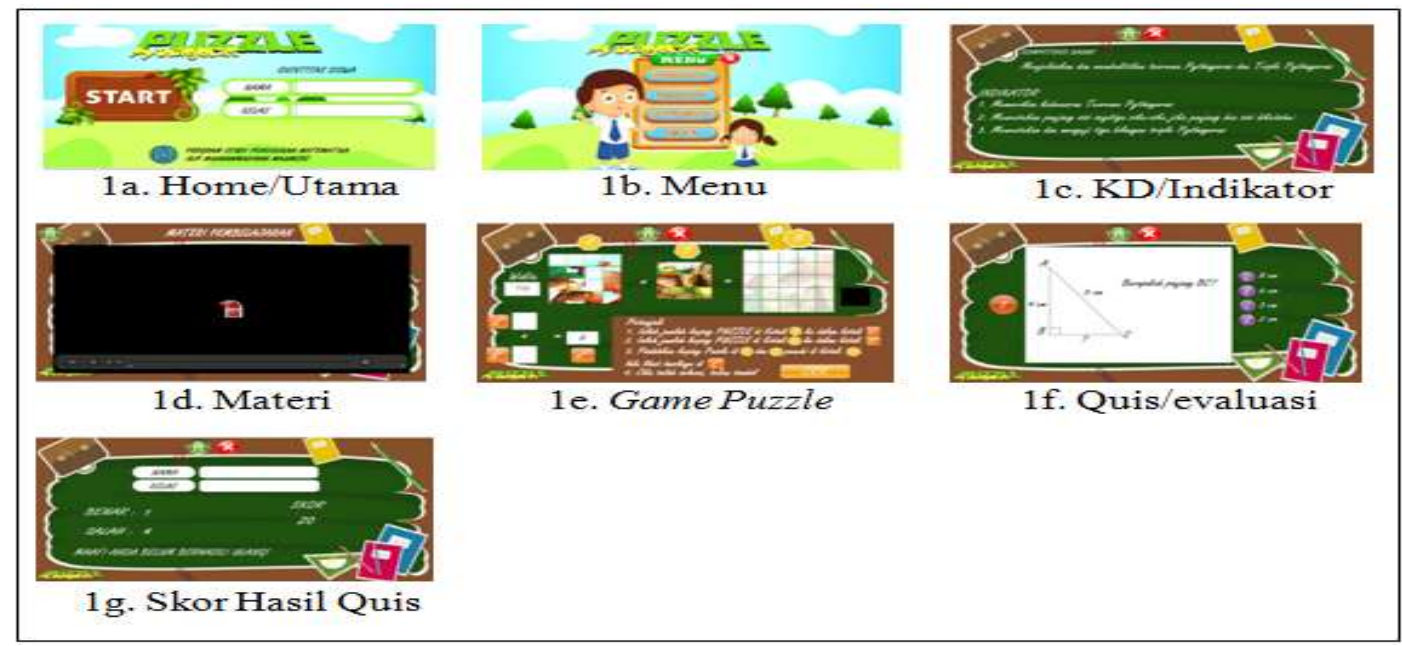

Gambar 1. Tampilan Media Sebelum Penilaian dan Revisi Ahli

Media yang dihasilkan kemudian dinilai oleh ahli materi dan ahli media menggunakan angket penilaian kelayakan media tahap 1. Hasil penilaian angket di tunjukkan oleh tabel 4. Hasil Penilaian Kelayakan Media Puzzle Square berikut:

\section{Tabel 4. Hasil Penilaian Kelayakan Media Oleh Ahli Tahap 1}

\begin{tabular}{|c|c|c|c|c|c|}
\hline No & Ahli & Aspek Penilaian & Komentar dan saran & $\begin{array}{l}\text { Total } \\
\text { Skor } \\
\left(\sum\right)\end{array}$ & $\begin{array}{l}\text { Rata- } \\
\text { Rata } \\
(X)\end{array}$ \\
\hline 1 & Materi & $\begin{array}{c}\text { Pembelajaran } \\
\text { dan isi }\end{array}$ & $\begin{array}{l}\text { - Menambahkan tombol untuk } \\
\text { mengulangi soal dari awal } \\
\text { setelah siswa sampai pada } \\
\text { halaman hasil. }\end{array}$ & 68 & 3,78 \\
\hline 2 & Media & $\begin{array}{l}\text { Tampilan dan } \\
\text { pemrograman }\end{array}$ & $\begin{array}{l}\text { Menambahkan tombol untuk } \\
\text { mengulangi soal dari awal } \\
\text { setelah siswa sampai pada } \\
\text { halaman hasil. } \\
\text { - Video pembelajaran } \\
\text { sebaiknya dipisah persub } \\
\text { materi dengan membuat } \\
\text { tombol masing-masing. } \\
\text { - Menambahkan tombol untuk } \\
\text { petunjuk media dan profil } \\
\text { pembuat. } \\
\text { Menambahkan gambar } \\
\text { pembuat atau suara pada } \\
\text { video materi. }\end{array}$ & 64 & 3,37 \\
\hline Rat & $\mathbf{a}(X$ & & & & 3,57 \\
\hline
\end{tabular}


Tabel 4 menunjukkan bahwa total skor penilaian ahli materi pada aspek pembelajaran dan isi sebesar 68 terhadap 18 indikator penilaian dengan rata-rata skor 3,78 yang termasuk dalam kategori baik. Total skor penilaian ahli media pada aspek tampilan dan pemrograman dengan 19 indikator penilaian mencapai 64 dengan rata-rata 3,37 yang termasuk dalam kategori cukup baik. Rata-rata penilaian ahli materi dan ahli media adalah 3,57 dengan kategori baik. Pada tabel tersebut juga ditunjukkan komentar dan saran ahli berdasarkan pengamatan pada media. Penilaian dan komentar serta saran ahli pada tahap 1 kemudian menjadi dasar dilakukannya revisi pada media. Berikut ditampilkan hasil revisi media berdasarkan penilaian ahli:

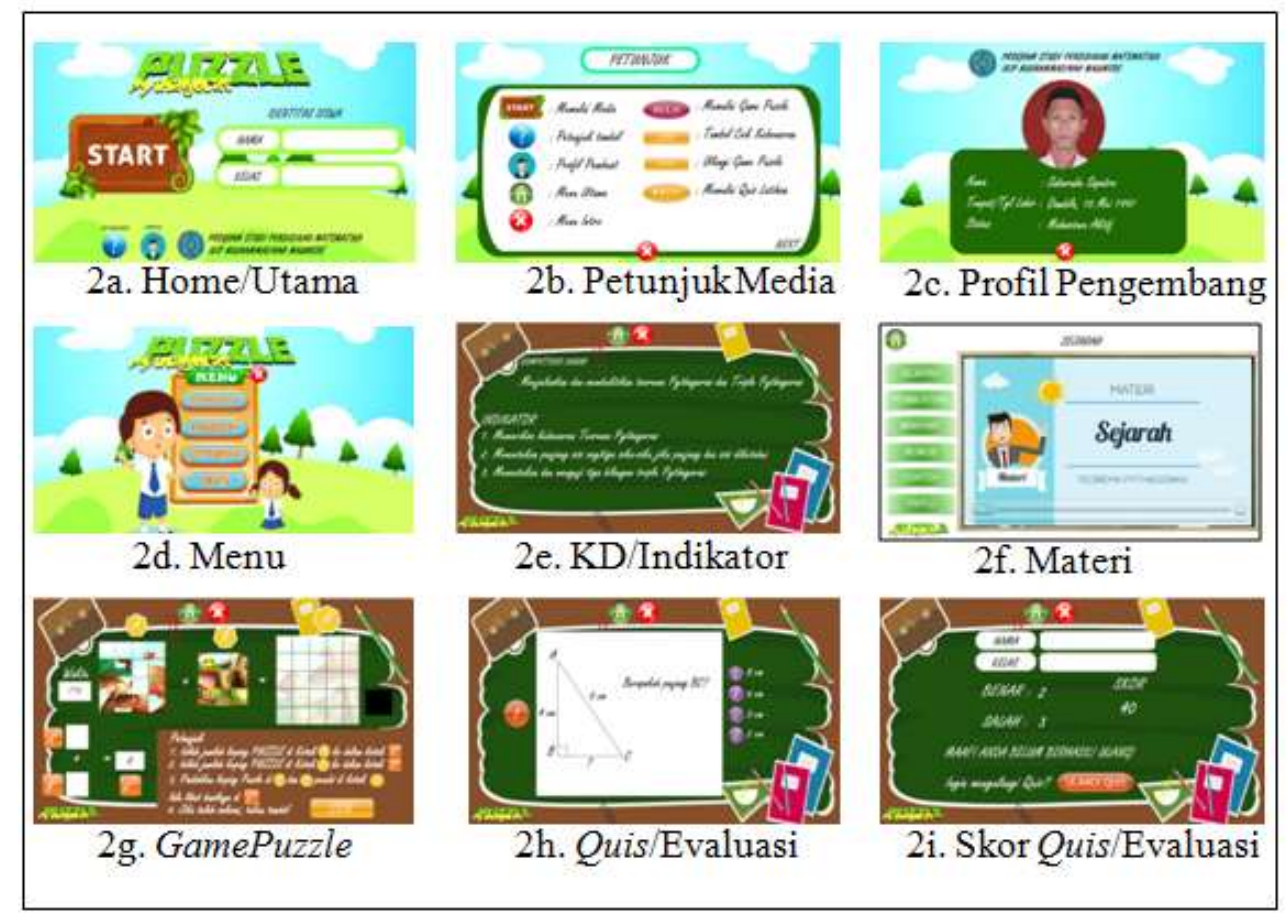

Gambar 2. Tampilan Media Setelah Penilaian dan Revisi Ahli Tahap 1

Gambar 2a. merupakan tampilan halaman Home/utama pada media pembelajaran. Pada halaman ini terdapat judul yaitu Puzzle Square Pythagoras, tombol navigasi "START", baris identitas peserta didik, identitas jurusan, tombol profil, dan tombol petunjuk. Tombol profil dan tombol petunjuk ditambahkan berdasarkan komentar dan saran ahli. Tombol profil akan mengarahkan pengguna ke halaman profil pengembang media seperti pada gambar 2c. sedangkan tombol petunjuk akan mengarahkan pengguna ke halaman petunjuk fungsi penggunaan setiap tombol yang akan ditemukan dalam media seperti yang ditampilkan oleh gambar $2 b$.

Menu media ditunjukkan pada gambar 2d. yang berisi kompetensi dan indikator pembelajaran, materi pembelajaran, pembuktian teorema Pythagoras dan quis singkat mengenai teorema Pythagoras. Tombol menu indikator mengarahkan pengguna pada halaman kompetensi dasar dan indikator pencapaian kompetensi seperti yang ditunjukkan oleh gambar 2e. Tombol menu materi mengarahkan ke halaman pembahasan teorema Pythagoras yang dipisahkan per sub materi seperti yang ditampilkan pada gambar $2 \mathrm{f}$. Materi pembahasan berupa video pembelajaran berbentuk animasi. Game Puzzle merupakan halaman yang menunjukkan 
pembuktian teorema Pythagoras sebagaimana yang ditampilkan oleh gambar $2 \mathrm{~g}$. ketika pengguna menekan tombol menu pembuktian. Menu quis mengarahkan pengguna pada soal-soal evaluasi yang ditampilkan gambar $2 \mathrm{~h}$. kemudian hasil evaluasi ditampilkan pada halaman hasil yang ditunjukkan oleh gambar $2 \mathrm{i}$.

Media yang telah melewati penilaian ahli dan perbaikan atau revisi tahap 1 dinilai kembali oleh ahli pada penilaian ahli tahap 2. Hasil penilaian ahli materi dan ahli media terhadap media ditunjukkan pada Tabel 5. Hasil Penilaian Kelayakan Media Oleh Ahli Tahap 2 berikut:

Tabel 5. Hasil Penilaian Kelayakan Media Oleh Ahli Tahap 2

\begin{tabular}{|c|c|c|c|c|c|}
\hline No & Ahli & Aspek Penilaian & $\begin{array}{l}\text { Komentar } \\
\text { dan saran }\end{array}$ & $\begin{array}{c}\text { Total Skor } \\
\left(\sum\right)\end{array}$ & $\begin{array}{c}\text { Rata-Rata } \\
(X)\end{array}$ \\
\hline 1 & Materi & \multirow{3}{*}{$\begin{array}{l}\text { Pembelajaran dan isi } \\
\text { Tampilan dan } \\
\text { pemrograman }\end{array}$} & - & 71 & 3,94 \\
\hline \multirow[t]{2}{*}{2} & Media & & - & 84 & 4,42 \\
\hline & Rata-rata & & & & 4,18 \\
\hline
\end{tabular}

Tabel 5 menunjukkan bahwa total skor penilaian ahli materi pada aspek pembelajaran dan isi sebesar 71 terhadap 18 indikator penilaian dengan rata-rata skor 3,94 yang termasuk dalam kategori baik. Total skor penilaian ahli media pada aspek tampilan dan pemrograman dengan 19 indikator penilaian mencapai 84 dengan rata-rata skor 4,42 yang termasuk dalam kategori sangat baik. Rata-rata penilaian ahli materi dan ahli media adalah 4,18 dengan kategori baik.

\section{Implementation (Penggunaan) \& Evaluation (Penilaian)}

Media pembelejaran yang telah dinyatakan baik oleh ahli dapat dilanjutkan pada tahap implementasi atau uji coba penggunaan. Uji coba penggunaan media dilakukan dua kali yaitu uji coba terbatas yang melibatkan 10 orang peserta didik dan uji coba kelompok besar yang melibatkan 31 orang peserta didik. Hasil penilaian pada uji coba terbatas dan uji coba kelompok besar ditunjukkan pada tabel 6 berikut:

Tabel 6. Hasil Penilaian Kelayakan Media Pada Uji Coba Pemakaian

\begin{tabular}{ccccc}
\hline No & Uji Coba & Aspek Penilaian & Total Skor $\left(\sum\right)$ & Rata-Rata $(\boldsymbol{X})$ \\
\hline 1 & Terbatas & & 541 & 4,16 \\
2 & Kelompok & 13 indikator penilaian media & 1.725 & 4,28 \\
& Besar & & & $\mathbf{4 , 2 2}$ \\
\hline
\end{tabular}

Hasil uji coba dan penilaian oleh peserta didik terhadap 13 indikator penialaian media pembelajaran yang ditunjukkan oleh tabel 6 . Berdasarkan tabel diperoleh total skor 541 dengan rata-rata 4,16 pada uji coba terbatas serta 1.725 dengan rata-rata 4,28 pada uji coba kelompok besar. Dari hasil kedua uji coba tersebut diperoleh rata-rata akhir yaitu 4,22.

Hasil pengembangan media interaktif Puzzle Square pada penelitian ini merupakan pengembangan lanjutan dari penelitian yang dilakukan oleh Mas'ud Rifai \& Erlina Prihatnani pada tahun 2020 dengan judul "Pengembangan Media Puzzle untuk Membuktikan Teorema Pythagoras" menghasilkan produk media bernama PuPPy yaitu Puzzle Pembuktian Pythagoras. Media ini disiapkan untuk memenuhi kebutuham pembelajran materi Pythagoras. Hasil penelitian 
menyatakan bahwa media PuPPy yang dikembangkan berdasarkan lima langkah model ADDIE dinyatakan valid, praktis dan efektif digunakan untuk mengkonstruksi siswa dalam belajar Pythagoras. Media pembelajaran interaktif Puzzle Square yang dikembangkan pada penelitian ini berbeda dengan media PuPPy pada penelitian sebelumnya karena Puzzle Square merupakan media pembelajaran berbasis program aplikasi komputer yang tidak hanya berisi pembuktian Pythagoras dengan konsep puzzle tetapi juga berisi video pembahasan materi dan quis.

Proses akhir dari tahapan pengembangan Puzzle Square adalah menganalisis hasil penilaian ahli materi, ahli media, dan peserta didik sebagai bentuk evaluasi terhadap kelayakan media. Media dinyatakan layak apabila hasil rata-rata skor minimal adalah 3,4 $<X<4,2$ dengan kriteria baik atau layak (Putra \& Ishartiwi, 2015). Berdasarkan hasil penelitian yaitu skor rata-rata dari ahli materi dan ahli media pada tahap 2 adalah 4,18. Mengacu pada tabel konversi penilaian maka media dinyatakan layak oleh ahli untuk diuji cobakan. Berdasarkan hasil uji coba dan penilaian oleh peserta didik diperoleh rata-rata skor 4,22. Mengacu pada tabel konversi penilaian media, nilai tersebut masuk dalam rentang $X>4,2$ dengan kategori sangat baik. Hasil penilaian tersebut sejalan dengan hasil penelitian (Putra \& Ishartiwi, 2015) yang menyatakan bahwa media layak digunakan dengan ratarata skor dari ahli materi sebesar 4,45 dan rata-rata skor dari ahli media sebesar 4,34 serta hasil penilaian oleh peserta didik yaitu anak usia dini mencapai rata-rata di atas $81 \%$ sehingga dinyatakan sangat layak digunakan dalam pembelajaran. Berdasarkan hasil penilaian tersebut maka media pembelajaran Puzzle Square dinyatakan layak digunakan sebagai media pembelajaran pada materi teorema Pythagoras di kelas VIII SMP Negeri 1 Maumere.

Penilaian ahli dan peserta didik terhadap media Puzzle Square sebagai media pembelajaran interaktif menggunakan Macromedia flash 8 pada materi teorema Pythagoras kelas VIII SMP Negeri 1 Maumere menghasilkan media yang memiliki kelebihan dari media sebelumnya yaitu (1) media dapat digunakan untuk belajar secara mandiri dengan memanfaatkan teknologi; (2) tampilan materi interaktif berbentuk video animasi, (3) media Puzzle Square sangat ringan dijalankan di komputer ataupun laptop; dan (4) media tidak membutuhkan kapasitas penyimpanan yang besar sehingga mudah disimpan.

\section{SIMPULAN}

Penelitian dan pengembangan ini menghasilkan aplikasi media pembelajaran yang berekstensi .exe yang dapat diakses menggunakan komputer. Berdasarkan hasil penilaian dan pembahasan maka media pembelajaran Puzzle Square dinyatakan layak digunakan sebagai media pembelajaran interaktif pada materi teorema Pythagoras di kelas VIII SMP Negeri 1 Maumere. Penelitian ini diharapkan dapat dilanjutkan kembali untuk menilai keefektifan penggunaan media dalam proses pembelajaran ataupun pengembangan lebih lanjut sesuai dengan kebutuhan pembelajaran.

\section{DAFTAR PUSTAKA}

Ahern, T. C. (2016). A Waterfall Design Strategy for Using Social Media for Instruction. Journal of Educational Technology Systems, 44(3), 332-345. https://doi.org/10.1177/0047239515615853

Akhmadan, W. (2017). Pengembangan Bahan Ajar Materi Garis dan Sudut 
Menggunakan Macromedia Flash dan Moodle Kelas VII Sekolah Menengah Pertama. Jurnal Gantang, 2(1), 27-40. https://doi.org/10.31629/jg.v2i1.62

Anjani, D. A., \& Nurjanah, S. (2018). Permainan Puzzle MempengaruhiPerkembangan Kecerdasan Visual-Spatial Anak Usia 4-5 Tahun Di TK Al-Fath Desa Keboan Anom Gedangan Sidoarjo. Journal of Health Sciences, 7(2), 186-192. https://doi.org/10.33086/jhs.v7i2.507

Asmawi, Syafei, \& Yamin, M. (2019). Pendidikan Berbasis Teknologi Informasi Dan Komunikasi. Prosiding Seminar Nasional Pendidikan, 50-55.

Budiman, H. (2017). Peran Teknologi Informasi Dan Komunikasi Dalam Pendidikan. Al-Tadzkiyyah: Jurnal Pendidikan Islam, 8(1), 31-43. https://doi.org/10.24042/atjpi.v8i1.2095

Crismono, P. C. (2017). Pengaruh Outdoor Learning Terhadap Kemampuan Berpikir Kritis Matematis Siswa. Junal Pendidikan Matematika Dan Sains, $5(2), 106-113$.

Fahmi, S. (2014). Pengembangan Multimedia Macromedia Flash Dengan Pendekatan Kontekstual dan Keefektifannya Terhadap Sikap Siswa Pada Matematika. Jurnal AgriSains, 5(2), 166-191. https://doi.org/10.1017/CBO9781107415324.004

Fatimah, D. D. S., Tresnawati, D., \& Ma'rup, C. S. (2017). Perancangan Game Puzzle Untuk Pembelajaran Menggunakan Metodologi Multimedia. Jurnal Algoritma, 14(2), 281-287. https://doi.org/10.33364/algoritma/v.14-2.281

Hidayati, E. W. (2018). Penggunaan Media Puzzle Konstruksi Terhadap Hasil Belajar Kognitif Siswa SDN Kemangsen II Krian. Indonesian Journal of Islamic Education Studies (IJIES), 1(1), 61-88. https://doi.org/10.33367/ijies.v1i1.519

Khairani, M., \& Febrinal, D. (2016). Pengembangan Media Pembelajaran Dalam Bentuk Macromedia Flash Materi Tabung Untuk SMP Kelas IX. Jurnal Iptek Terapan, 10(2), 95-102. https://doi.org/10.22216/jit.2016.v10i2.422

Kurniawan, D., \& Saragih, A. H. (2016). Pengembangan Bahan Pembelajaran Media Interaktif Pada Mata Pelajaran PPKN. Jurnal Teknologi Informasi \& Komunikasi Dalam Pendidikan, 3(1). https://doi.org/10.24114/jtikp.v3i1.5001

Lee, W. W., \& Owens, D. L. (2012). Multimedia-Based Instructional Design. In Pfeiffer. https://doi.org/10.1007/s13398-014-0173-7.2

Masykur, R., Nofrizal, N., \& Syazali, M. (2017). Pengembangan Media Pembelajaran Matematika dengan Macromedia Flash. Al-Jabar: Jurnal Pendidikan Matematika, 8(2), 177-186. https://doi.org/10.24042/ajpm.v8i2.2014

Muhayat, U., Wahyudi, W., Wibawanto, H., \& Hardyanto, W. (2017). Pengembangan Media Edukatif Berbasis Augmented Reality untuk Desain Interior dan Eksterior. Innovative Journal of Curriculum and Educational Technology, 6(2), 39-48. https://doi.org/10.15294/ijcet.v6i2.19337

Mustamid, M., \& Raharjo, H. (2015). Pengaruh Efektifitas Multimedia Pembelajaran Macromedia Flash 8 Terhadap Motivasi Belajar Siswa Pada Materi Fungsi Komposisi Dan Invers. Eduma: Mathematics Education Learning and Teaching, 4(1), 26-42. https://doi.org/10.24235/eduma.v4i1.21

Nurdyansyah, M., Pd, A., \& Widodo, M. M. (2015). Inovasi Teknologi Pembelajaran. Nizamial Learning Center.

Pradipta, R. F., \& Andajani, S. J. (2017). Motion Development Program for Parents of Child with Cerebral Palsy. Jurnal Penelitian Dan Pengembangan 
Pendidikan Luar Biasa, 4(2), 160-164.

Putra, L. D., \& Ishartiwi, I. (2015). Pengembangan Multimedia Pembelajaran IInteraktif Mengenal Angka dan Huruf Untuk Anak Usia Dini. Jurnal Inovasi Teknologi Pendidikan, 2(2), 169-178. https://doi.org/10.21831/tp.v2i2.7607

Putri, Q. K., Pratjojo, P., \& Wijayanti, A. (2019). Pengembangan Media Buku PopUp untuk Meningkatkan Kemampuan Menyimak Tema Menyayangi Tumbuhan dan Hewan di Sekitar. Jurnal Pedagogi Dan Pembelajaran. https://doi.org/10.23887/jp2.v2i2.17905

Rifai, M., \& Prihatnani, E. (2020). Pengembangan Media Puzzle Untuk Pembuktian Teorema Pythagoras. Delta: Jurnal Ilmiah Pendidikan Matematika, 8(1), 4160. https://doi.org/10.31941/delta.v8i1.953

Setiawan, T., \& DS, S. H. (2013). Sikap Guru Taman Kanak-Kanak Terhadap Pembelajaran Matematika. Jurnal Ilmu Pendidikan, 19(1), 50-55.

Setyawati, H. (2017). Pengembangan Perangkat Pembelajaran Berbasis Masalah untuk Meningkatan Keterampilan Proses Sains Siswa. Jurnal Bioedukasi, $15(1), 32-42$.

Sugiyono. (2012). Metode Penelitian Kuantitatif, Kualitatif dan R \& D.Bandung:Alfabeta. Metode Penelitian Kuantitatif, Kualitatif Dan $R$ \& D.Bandung:Alfabeta. https://doi.org/10.1017/CBO9781107415324.004

Susilana, R., \& Riyana, C. (2009). Media Pembelajaran: Hakikat, Pengembangan, Pemanfaatan, dan Penilaian. In Media Pembelajaran. https://doi.org/10.3168/jds.2017-13062

Wati, Ega Rima. 2016. Ragam Media Pembelajaran. Yogyakarta: Kata Pena

Widjayanti, W. R., Masfingatin, T., \& Setyansah, R. K. (2018). Media Pembelajaran Interaktif Berbasis Animasi Pada Materi Statistika Untuk Siswa Kelas 7 SMP. Jurnal Pendidikan Matematika, 13(1), 101-103. https://doi.org/10.22342/jpm.13.1.6294.101-112

Yektyastuti, R., \& Ikhsan, J. (2016). Pengembangan media pembelajaran berbasis android pada materi kelarutan untuk meningkatkan performa akademik siswa SMA. Jurnal Inovasi Pendidikan IPA, 2(1), 88-99. https://doi.org/10.21831/jipi.v2i1.10289 